Anais da Academia Brasileira de Ciências (2012) 84(2): 509-515

(Annals of the Brazilian Academy of Sciences)

Printed version ISSN 0001-3765 / Online version ISSN 1678-2690

www.scielo.br/aabc

\title{
Influence of the nycthemeral cycle on the roosting behaviour of the Orange-winged Amazon
}

\author{
LEILIANY N. DE MOURA ${ }^{1}$, MARIA LUISA DA SILVA ${ }^{1}$ and JACQUES M.E. VIELLIARD ${ }^{2 *}$ \\ ${ }^{1}$ Laboratório de Ornitologia e Bioacústica, Instituto de Ciências Biológicas, Universidade Federal do Pará, \\ Rua Augusto Corrêa, 01, 66075-110 Belém, PA, Brasil \\ ${ }^{2}$ Laboratório de Bioacústica, Instituto de Biologia, Universidade Estadual de Campinas, \\ Cidade Universitária Zeferino Vaz, Rua Monteiro Lobato, 255, 13083-862 Campinas, SP, Brasil
}

Manuscript received on November 18, 2010; accepted for publication on August 19, 2011

\begin{abstract}
Environmental stimuli exert important effects on the expression of the endogenous rhythms. Daily movements of groups of parrots in response to the light/dark cycle have been studied by several researchers. However, the factors modifying the intrinsic rhythmicity of this behaviour remain little known. This study describes how the nychthemeral/circadian periodicity of roost daily movements of the Orange-winged Amazon Amazona amazonica is modified by weather factors. Numbers of parrots arriving or leaving the roosting site Ilha dos Papagaios were determined on a minute by minute basis. More parrots have significantly arrived at the roost after sunset than before, while more parrots have significantly left the roost before sunrise than after. The peak exodus of parrots occurred at $23 \pm 5.24$ minutes before sunrise, when the average light intensity was 1 lux. The peak influx of parrots occurred at $6 \pm 6.1$ minutes after sunset, when the average light intensity was 50 lux. By altering ambient light intensity, weather conditions have significantly influenced the arrival and departure times, with parrots leaving later and arriving earlier when conditions were overcast at the roost site.
\end{abstract}

Key words: Amazona amazonica, Amazônia, biological rhythms, light/dark cycles, roosting behaviour, weather conditions.

\section{INTRODUCTION}

Biological rhythms of activity/rest related to light/ dark cycles are referred as nycthemeral cycles, and have been found in organisms ranging from simple unicellular prokaryotic cyanobacterias to mammals. They confer an adaptive advantage on the organism by allowing it to adjust its physiology and behaviour in anticipation of changes in the environment (Forattini et al. 1981, Hall and Rosbash 1993, Menaker et al. 1997, Sheeba et al. 1999, MennaBarreto 2003, Paranjpe and Sharma 2005).

\footnotetext{
* In memoriam

Correspondence to: Leiliany Negrão de Moura

E-mail: leilianym@gmail.com
}

From a physical point of view, the alternation of light and dark forms is the primary demarcation of daily time. In order to adjust their physiological systems to daily variations in the environment, living organisms need (1) an endogenous clock, that is pre-programmed to correspond with the daily environmental pattern; (2) sense organs, which can detect abnormalities in the environmental rhythm; and (3) neural systems, which can alter the intrinsic rhythm in response to the sensory information (Markus et al. 2003).

Nycthemeral rhythms are fundamental for the temporal organization of the behaviour and physiology of birds. Compared with mammals, 
birds are equipped with rather complex and diverse diurnal pacemaker systems that correspond to the complexity and diversity of the various lifestyles birds have evolved in a variety of different environments (Gwinner and Brandstätter 2001). Perception of the photic environment by birds is achieved by retinal, pineal and deep encephalic photoreceptors (Cassone and Menaker 1984). These three components interact jointly with each other to regulate the behavioural and physiological rhythmicity: the pineal gland, by rhythmically releasing melatonin, a hormone that plays a central role in the circadian organization of birds; the hypothalamic oscillator, possibly acting through neural output signals; and the retina, acting either via periodic melatonin secretion or neural output signals (Cassone and Menaker 1984, Gwinner and Brandstätter 2001, Brandstätter 2003).

Among birds, some parrots had been studied in relation to their daily roosting behaviour (Rocha et al. 1988, Mabb 1997, Harms and Eberhard 2003, Cougill and Marsden 2004, P.C.R. Costa, unpublished data). However, the factors influencing the time of arrival and departure of parrots in roosts are still little known (Sick 1997). The aim of this study was to determine the influence of ambient light conditions on the dynamics of daily movements of the Orange-winged Amazon Amazona amazonica at the roosting site Ilha dos Papagaios in Belém, Pará, Brazil.

\section{METHODS}

\section{STUDY AREA}

Ilha dos Papagaios is a roosting site for a significant Orange-winged Amazon population, a common species in the region. It is located in Guajara Bay, south of Belém, Brazil (01³1'16”S, 48³0'23”W), and has an area of 7.4 ha. The island is low and subject to periodic tidal flooding (Novaes and Lima 1998).

The climate is tropical humid and the source of seasonality is precipitation, although there is no pronounced dry season. There are two seasons: a rainy season and a weak dry season. The rainy season begins in December, with a peak in March, and subsides in May. January, February and March are the wettest months, with average monthly rainfalls exceeding 400 $\mathrm{mm}$. The less rainy season usually corresponds to the period from June to November, and October is the driest month with an average precipitation of $86 \mathrm{~mm}$ (annual precipitation $=2800 \mathrm{~mm}$ ). Temperatures are typically high at every month of the year, resulting in an annual average of $26^{\circ} \mathrm{C}$, with a thermal amplitude of approximately $8^{\circ} \mathrm{C}$ (minimum monthly average of $23^{\circ} \mathrm{C}$ and maximum of $31^{\circ} \mathrm{C}$ ). Relative air humidity has an annual average of about $80 \%$ and reaches $90 \%$ in the period from December to June (SECTAM 1994).

The vegetation is mostly ombrophilous dense alluvial forest, with emergent and uniform canopy in areas of lowland floodplain. Flooded forests and sandy alluvial deposits (beaches) covered by scarce vegetation, which are characteristic of Guajara Bay as a whole, are also present (Novaes and Lima 1998).

\section{FIELD METHODS}

We observed 63 arrivals at the roost and 50 departures from ( $n=113$ days) between September 2004-September 2005 and between AugustDecember 2006. Parrots were observed from a medium-sized boat positioned in a strategic point (south-east of the island), from where it was possible to clearly observe the parrots' arrival and departure.

When possible, two visits were done every week, one in the afternoon, between 17:00-19:00 h, and the other in the morning of the following day, between 05:00-8:00 $\mathrm{h}$, beginning before sunset and sunrise, respectively. Estimates of arriving or departing parrots were made continuously on a per minute basis throughout the observation period by three teams each in a different part of the boat. Each team consisted of at least one observer and one 
auxiliary. The observers announced the number of all arriving or departing parrots as seen with the aid of 7x50 binoculars, being careful not to duplicate individuals already counted by themselves or by another team. The auxiliaries recorded the data, controlled the digital chronometer and registered environmental data.

Weather conditions were represented by codes $(\mathrm{C} 1=$ cloudless; $\mathrm{C} 2=$ overcast; $\mathrm{R} 1=$ without rain; $\mathrm{R} 2$ = raining). Data on temperature and humidity were obtained with a thermhygrometer (Oregon Scientific). Wind speed was determined with a digital anemometer (MANUFACTURER, AD250). Local luminosity was measured minute by minute with a luxmeter (MANUFACTURER, LD201 Minolsystem).

Data were analyzed with Statistica Software 7.1 (Statsoft Inc. 2005) and were expressed as means $\pm \mathrm{sd}$. Variables were examined for normality using Kolmogorov-Smirnov tests. The MannWhitney nonparametric test was used when the distribution of values differed significantly from normality, and in normal distribution Student's t-test for independent samples and Pearson's correlation were used. The tests were considered statistically significant at $P<0.05$.
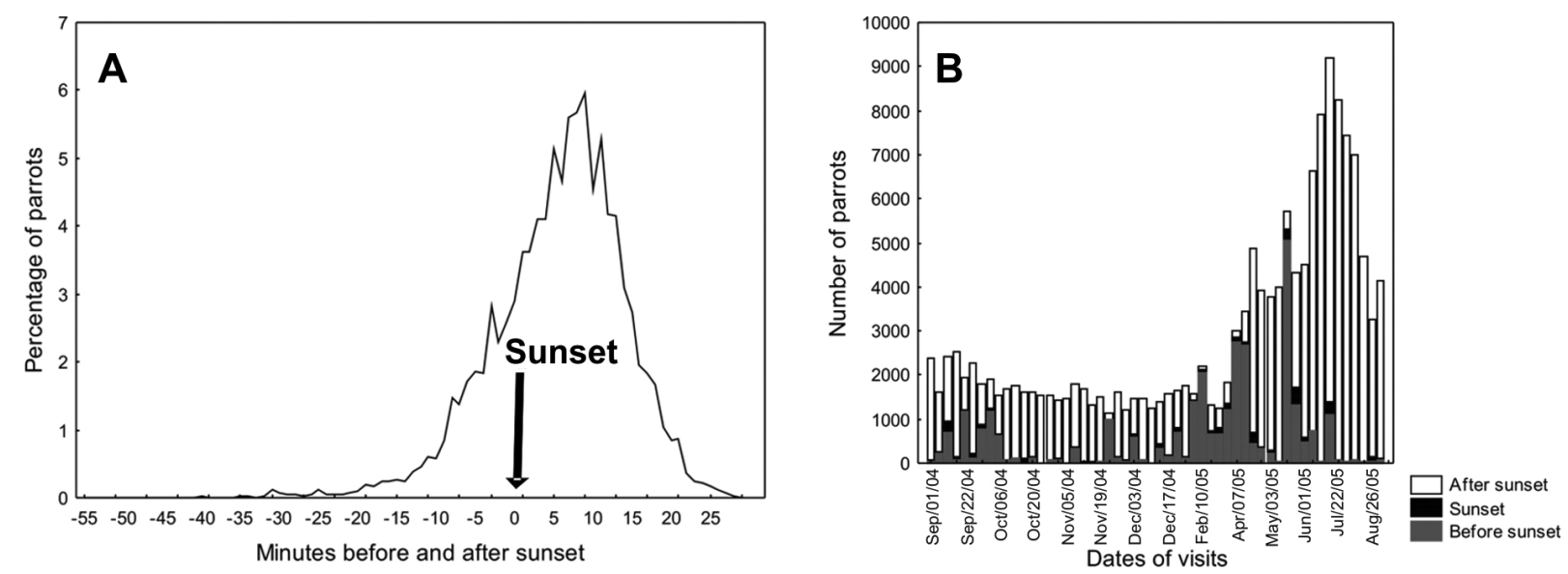

Fig. 1. A Results for a typical observation period showing the percentage of parrots arriving at the roosting site minute by minute before and after sunset. B Results for all observation periods showing the number of parrots arriving before, during and after sunset. 
of individuals arriving after sunset (Pearson's correlation: $\left.r_{56}=0.544, P<0.0001\right)$. There was a moderate negative correlation between humidity and the number of individuals arriving after sunset $\left(r_{56}=-0.519, P<0.0001\right)$. There was no statistical correlation between the wind speed and the arrival time of parrots $\left(r_{9}=0.48, P=0.186\right)$.

Considering the amount of local luminosity (lux) at the moment of sunset ( $280 \pm 150.8 \mathrm{lux}$ ), we verified that on average $94 \pm 5.4 \%$ of individuals arrived at light intensities between 300-2 lux, with most parrots arriving at 50 lux (Fig. 2). There was a strong negative correlation between the luminosity and the arrival time of parrots. When luminosity at sunset reduces, more individuals arrives at the roost $\left(r_{43}=-0.75, P<0.0001\right)$.

On cloudy or rainy days the light intensity at sunset is lower than in sunny or cloudless days (cloudless days $=421 \pm 161$ lux vs cloudy days $=210$ \pm 90 lux; without rain $=345 \pm 145$ lux vs rainy days $=150 \pm 18$ lux).

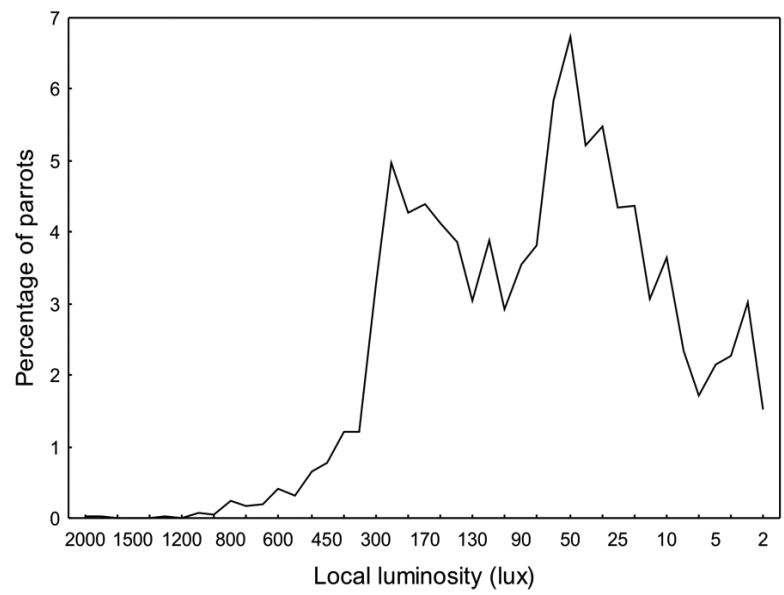

Fig. 2. Average percentile rank for individuals arriving at the roosting site, considering the gradient of luminosity.

\section{DEPARTURE OF PARROTS From THE RoOSTING SITE AND}

ABIOTIC FACTORS

For 49 out of 50 observation periods, the majority of parrots left the roost site before sunrise (before sunrise $=76 \pm 15 \%$ vs after sunrise $=24 \pm 15 \%$, $U=87.5, P<0.0001$; Fig. 3).
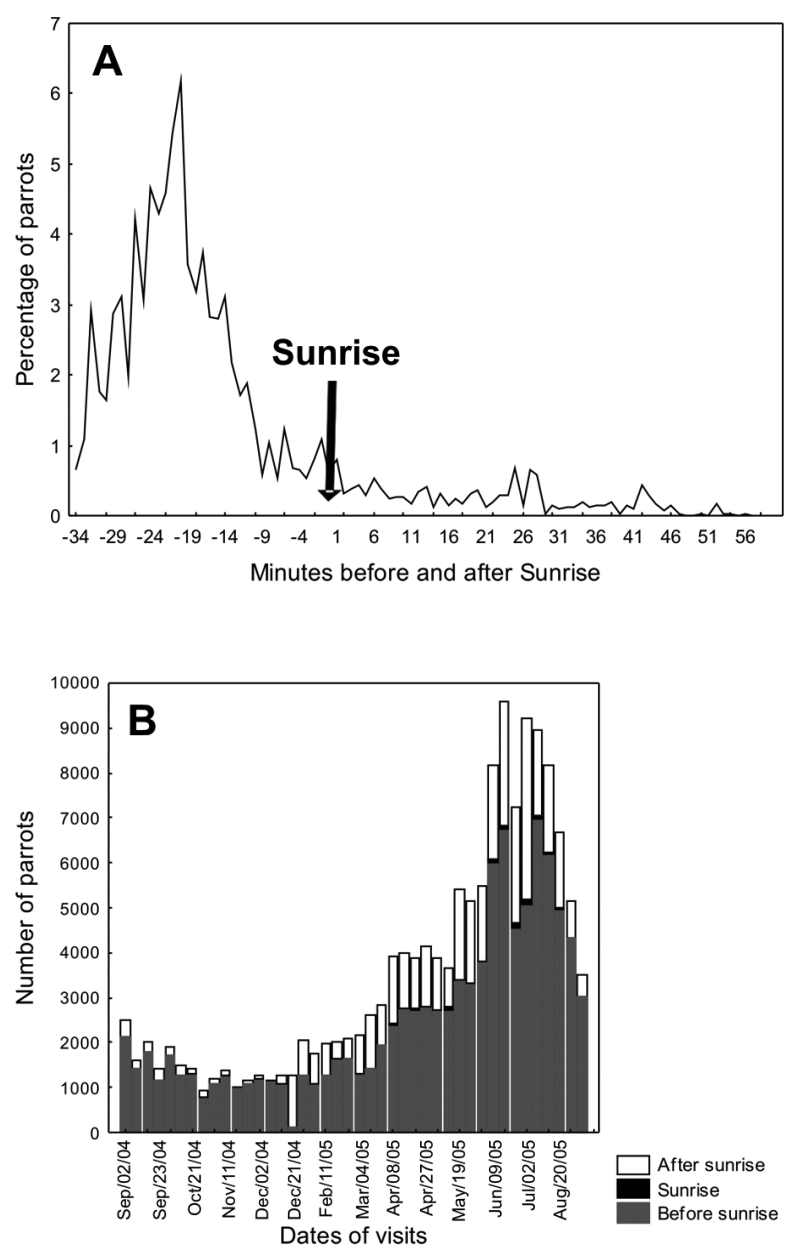

Fig. 3. A Representative observation period showing the percentage of parrots leaving the roosting site minute by minute before and after sunrise. B Number of parrots leaving the roost site before or after sunset for all observation periods.

On average, the first parrots left the roost site at $29 \pm 4.95$ minutes before sunrise, and the peak of departure occurred at $23 \pm 5.24$ minutes before sunrise.

On cloudless days $(\mathrm{C} 1)$, the number of individuals leaving the roosting site before sunrise (BS) was greater than when the sky was overcast $(\mathrm{C} 2)$ $\left(\mathrm{BSC} 1=79 \pm 10 \%\right.$ vs BSC $2=63 \pm 21 \%, t_{48}=3.59$, $P=0.0009)$. It was not possible to test if rain influenced in the departure of parrots because it rained during only four morning observation periods.

There were no statistically significant correlations between temperature, humidity or 
wind speed with the time of departure of parrots $\left(r_{44}=-0.235, P=0.124 ; r_{44}=0.0019, P=0.99\right.$; $r_{8}=0.335, P=0.462$, respectively).

Average luminosity at sunrise was $299 \pm 88$ lux, and $83 \pm 5.42 \%$ of parrots left the roost site at luminosities between 1-300 lux, with a peak of departure at 1 lux (the minimum measurable luminosity; Fig. 4). There was a weak negative correlation between the luminosity and the time of departure of parrots. When the luminosity reduces, more individuals leave the roost $\left(r_{59}=-0.30, P=0.02\right)$.

On cloudy or rainy days, the light intensity at sunrise is lower than in cloudless days (cloudless days $=339 \pm 40$ lux vs cloudy days $=181 \pm 93$ lux).

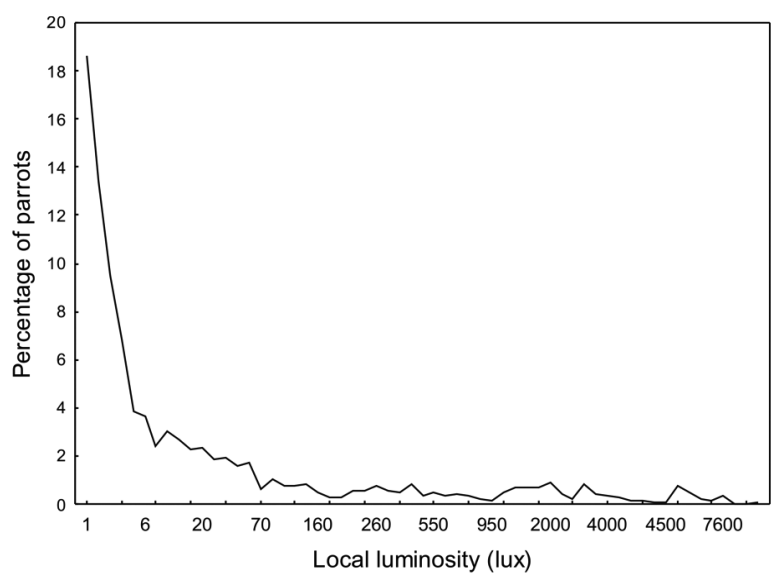

Fig. 4. Dependence of the percentage of parrots leaving on luminosity.

\section{DISCUSSION}

The ability to perceive and respond to changes in luminosity is a feature of the biological clock in all organisms, and luminosity is frequently the main modifier of intrinsic circadian rhythms (Randall et al. 2000). Here we describe the effects of the light/ dark cycle on the synchronization of the arrival and departure of the parrot $A$. amazonica at its roost.

Although the Orange-winged Amazon is a diurnal bird, it travels from and to its roosts during periods of low luminosity. These data corroborate many other studies detailing the importance of the crepuscular periods in the behaviour of parrots (Sick 1997).
Observations of some parrot species have suggested that their arrival at the roost site is largely complete by sunset (Rocha et al. 1988, Harms and Eberhard 2003, P.C.R. Costa, unpublished data). For instance, according to P.C.R. Costa (unpublished data), the majority of White-winged Parakeets Brotogeris versicolurus arrives at their roost site before sunset, taking advantage of the last daylight for feeding before perching in the Kapok trees Ceiba petandra, where they habitually roost. However, in this work we show that $75 \%$ of the population of A. amazonica studied arrives after sunset.

Our finding that the majority of parrots leave the roost site before sunrise is in agreement with the results of Rocha et al. (1988) for a mixed roost of five parrot species leaving to spend the daylight hours in Terra firme forest. However, our data contrast with those of Harms and Eberhard (2003), who found that Aratinga pertinax individuals left the roost site after sunrise.

Daily movements of parrots were described by Forshaw (1966), and the use of roost sites could be to provide a more protected night shelter from predators than those available in Terra firme forests (Lazarus 1972, Snyder et al. 1987). However, we have no data of relevance to this hypothesis. The return from the roost site to Terra firme forest is presumably related to inadequate food supplies for the high number of parrots at the roost (Rocha et al. 1988).

Weather conditions exert important influences on the expression of endogenous rhythms by promoting adjustments through specific biological mechanisms, with each species having defined limits in their responsiveness (Rotenberg et al. 2003). On overcast and rainy afternoons it gets dark earlier, and temperature is lower and humidity higher than on cloud-free afternoons. The parrots respond to change in luminosity by arriving earlier at the roost site. Similarly, the reduction of luminosity on overcast mornings leads to a delayed departure from the roost site. These effects were confirmed here for Amazona 
brasiliensis, with individuals arriving at the roost site more than three hours before sunset on overcast days (Cougill and Marsden 2004).

In conclusion, adverse weather conditions such as cloudiness and rain can act as masking agents, modifying the biological rhythm of species, in this case the times of arrival and departure of $A$. amazonica at its roost site. The ability to quickly modify nycthemeral rhythms in response to changes in ambient conditions adds an important level of adaptive plasticity to the animal's temporal response to its environment (Marques et al. 2003).

\section{ACKNOWLEDGMENTS}

We thank A. P. Assumpção, C. Araújo, D. O. Ferraz, E. R. Oliveira, I. Brcko, K. Pereira, J. L. Magalhães, P. R. Costa, R. Emin-Lima and V. S. Lima for assistance over field works; Dr. J. Widdicombe for the revision of an earlier draft; and PARATUR and Coordenação de Aperfeiçoamento de Pessoal de Nível Superior (CAPES) for financial support to this project.

\section{RESUMO}

Estímulos ambientais exercem efeitos importantes na expressão de ritmos endógenos. Deslocamentos diários de grupos de psitacídeos em resposta ao ciclo claro/ escuro têm sido estudados por alguns autores. Todavia, os fatores que influenciam a ritmicidade intrínseca deste comportamento não são bem conhecidos. Este estudo descreve como a periodicidade nictemeral/ circadiana dos deslocamentos diários de dormitórios do Papagaio-do-mangue Amazona amazonica é modificada por fatores climatológicos. Os números de papagaios chegando ou deixando o dormitório Ilha dos Papagaios foram determinados de minuto a minuto. Um número significativamente maior de papagaios chegou ao dormitório após o ocaso, enquanto que um número significativamente maior de papagaios deixou o dormitório antes da aurora. O pico de saída dos papagaios ocorreu $23 \pm 5,24$ minutos antes da aurora, quando a média de intensidade de luz era de 1 lux. O pico de chegada de papagaios ocorreu $6 \pm 6,1$ minutos após o ocaso, quando a média de intensidade de luz era de 50 lux. Ao alterar a intensidade de luz do ambiente, as condições climatológicas influenciaram significativamente os horários de chegada e saída, com papagaios deixando o dormitório mais tarde ou chegando mais cedo em condições de nebulosidade alta.

Palavras-chave: Amazona amazonica, Amazônia, ritmos biológicos, ciclos claro/escuro, comportamento de pernoitar em dormitórios, condições climatológicas.

\section{REFERENCES}

BRANDSTÄTTER R. 2003. Encoding time of day and time of year by the avian circadian system. J Neuroendocrinol 15: 398-404.

CASSONE VM AND MENAKER M. 1984. Is the avian circadian system a neuroendocrine loop? J Exp Zool 232: 539-549.

COUGILl S AND MARSDEN SJ. 2004. Variability in roost size in an Amazona parrot: implications for roost monitoring. J Field Ornithol 75: 67-73.

FORATTINI OP, GOMES AC, SANTOS JLF, GALATI EAB, RABELLO EX AND NATAL D. 1981. Observações sobre atividade de mosquitos Culicidae, em mata residual no Vale do Ribeira, S. Paulo, Brasil. Rev Saúde Publ 15: 557-586.

FORSHAW JM. 1966. Observations and systematic notes on the red-cheecked parrot. Mem Qd Mus 14: 175-180.

GWINNER EAND BRANDSTÄTTER R. 2001. Complex bird clocks. Phil Trans R Soc B 356: 1801-1810.

HALL JC AND ROSBASH M. 1993. Oscillating molecules and how they move circadian clocks across evolutionary boundaries. Proc Natl Acad Sci USA 90: 5382-5383.

HARMS KE AND EBERHARD JR. 2003. Roosting behavior of the brown-throated parakeet (Aratinga pertinax) and roost locations on four southern caribbean islands. Ornit Neot 14: 79-89.

LAZARUS J. 1972. Natural selection and the functions of flocking in birds: a replay to Murton. Ibis 114: 556-558.

MABB KT. 1997. Roosting behavior of naturalized parrots in the San Gabriel Valley, California. Western Birds 28: 202-208.

MARKus RP, AFEChE SC, BARbosa JR EM, Lotufo CMC, FERREIRA ZS AND CIPOLA-NETO J. 2003. Glândula Pineal e Melatonina. In: MARQUES NAND MENNA-BARRETO L (Eds), Cronobiologia: princípios e aplicações, São Paulo: Edusp, São Paulo, Brasil, p. 191-222.

MARQUES MD, GOLOMBEK D AND MORENO C. 2003. Adaptação Temporal. In: MARQUES N AND MENNA-BARRETO L (Eds), Cronobiologia: princípios e aplicações, São Paulo: Edusp, São Paulo, Brasil, p. 55-98. 
MenAKer M, Moreira LF AND TOSINI G. 1997. Evolution of circadian organization in vertebrates. Braz J Med Biol Res 30: 305-313.

MENNA-BARRETOL. 2003. O tempo na Biologia. In: MARQUES N AND MENNA-BARRETO L (Eds), Cronobiologia: princípios e aplicações, São Paulo: Edusp, São Paulo, Brasil, p. 26-29.

NovaEs FC AND Lima MFC. 1998. Aves da Grande Belém: Municípios de Belém e Ananindeua. Belém: Ed. Museu Paraense Emílio Goeldi.

PARANJPE DA AND SHARMA VK. 2005. Evolution of temporal order in living organisms. J Circad Rhythms 3: 7-19.

RANDALL D, BURGgREN W AND FRENCH K. 2000. Fisiologia Animal: Mecanismos e Adaptações. Rio de Janeiro: Guanabara Koogan.

Rocha CED, BERGALlo HG AND SiCILIANO S. 1988. Migração circadiana em cinco espécies de psitacídeos em ParintinsAM. Acta Amaz 18: 371-374.
Rotenberg L, Marques N ANd MennA-BArReto L. 2003. História e Perspectivas da Cronobiologia. In: MARQUES N AND MENNA-BARRETO L (Eds), Cronobiologia: princípios e aplicações, São Paulo: Edusp, São Paulo, Brasil, p. 31-53.

SECTAM. 1994. Parque ambiental de Belém: Plano e manejo. Rio de Janeiro: Sofrelec Engenharia.

SHEEBA V, SHARMA VKand Joshi A. 1999. Adaptive significance of circadian rhythms. Resonance Jan, p. 73-75.

SICK H. 1997. Ornitologia Brasileira. Rio de Janeiro: Nova Fronteira. SNYDER NFR, WILEY JW AND KEPLER CB. 1987. The parrots ok Luquilo: natural history and conservation of the Puerto Rican parrot. Los Angeles: Western Foudation of Vertebrate Zoology. 